\title{
De ferske vandes kulturhistorie i Danmark - brugen af de ferske vådområder gennem tiderne
}

Af geolog Per S. Sundberg, GeologiskNyt

Formålet med "De ferske vandes kulturhistorie i Danmark" er at give en samlet beskrivelse af den kulturhistorie, som knytter sig til de danske vådområder. Bogen er opbygget af en række artikler skrevet af forskellige fagfolk og eksperter.

Bag den lidt kedelige titel gemmer sig en meget interessant bog. Den er opbygget i 11 hovedafsnit, der hver dækker over et antal artikler, skrevet af en række på hele 36 fagfolk og eksperter fra bl.a. museer, universiteter og videncentre. I alt 43 artikler er der præsenteret i bogen, og de danner en samlet beskrivelse af den kulturhistorie, som knytter sig til de danske vådområder. Artiklerne spænder vidt både tids- og emnemæssigt. Man kommer omkring vådområdernes dannelse og dyreliv samt udforskning, deres betydning for erhverv, bebyggelse, transport og færdsel, sprog og grænser, rekreation, religion, kunst og litteratur samt regulering og administration. Der er således noget at hente for mange læsere.

Vidste du, at dambrug ....

Hvem tænker på, at dambruget i Danmark har en århundrede lang historie bag sig? Det er nemlig en af de ting, man kan læse sig til i bogen. Selv har jeg kun tænkt på dambrug som et nymodens og nærmest industriagtigt, landskabs- og vandløbsforstyrrende erhverv og aldrig overvejet, at det også har en historie. Fiskedamme nævnes i skriftlige kilder allerede tilbage i 1200 -årene, men om der har været tale om egentligt fiskeopdræt er mere tvivlsomt. Men man ved med sikkerhed, at fra1500-årene og frem udviklede dambrugsdriften sig hastigt og var tæt knyttet til godser og slotte, altså primært adelen. Og det var ikke småting, der blev produceret. Fx skulle hoffet i 1600-årene have leveret 22 tons fisk årligt fra de nordsjællandske len. Op gennem dette århundrede har der været en stigende eksport fra dambrugene, og der blev til stadighed etableret flere og flere brug, der antalsmæssigt toppede i 60'erne med ca. 800 og en produktion på ca. 12.000 tons ørreder. I 70'erne kom der fokus på vandløbsforurening og siden da har stigende miljøkrav nødvendiggjort omlægninger i branchen. Ikke desto mindre var produktionen i 2000 på ca. 33.000 tons ørreder.

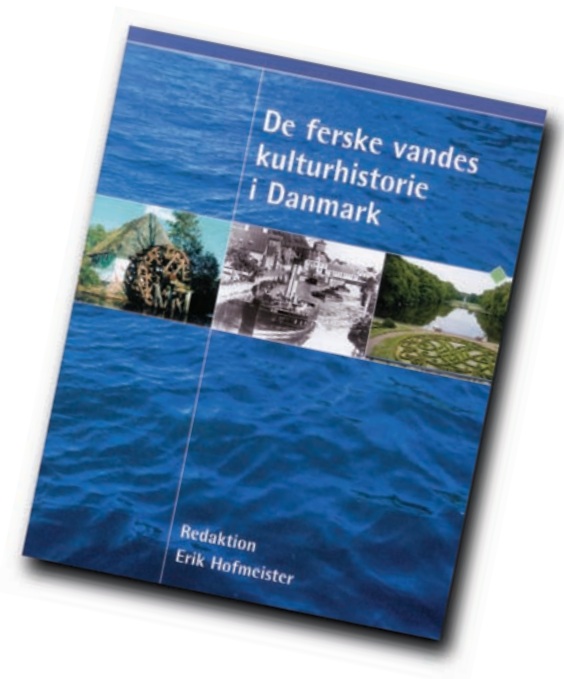

lens titel er angivet med hvidt, og hovedafsnittets titel er på frisk vis angivet nederst på siden. Samme farve går igen i bjælke, sidefod samt artikeloverskrift og skifter med hvert hovedafsnit. Titlen kunne også godt have været mere appetitvækkende. Det er synd for så glimrende en bog, at den har denne visuelt kedelige fremtoning.

Bogen er ellers velskrevet og letlæselig. Den er skrevet af folk, der kan formidle deres stof til et bredere publikum på en let og ubesværet måde og med engagement. Bogen er suppleret med mange vedkommende og flotte illustrationer. Kan klart anbefales til alle, der bevæger sig inden for rammerne af natur- og kulturhistorien.

"De ferske vandes kulturhistorie i Danmark" er udgivet af AQUA Ferskvands Akvarium under redaktion af cand. mag. Erik Hofmeister, AQUA Ferskvands Akvarium. Udgivelsen er støttet af en rcekke fonde. Bogen er på 407 sider og koster kr. 395, ISBN: 87-91355-09-5.I
Lidt for geologer

I bogen finder man da også emner at interesse for geologer. Fx den indledende artikel om dannelsen af søer og vandløb, der nok kan vække visse erindringer til live i selv en henslumrende geologhjerne. Man får således bl.a. opfrisket de forskellige landskabstyper med deres forekomster af søer og vandløb. Der er også artiklen om råstoffer fra de ferske vande. Her kigger man på myremalm, mergel, diatomejord, tørv og sphagnum. Godt nok beskæftiger man sig mest med udnyttelsen af råstofferne, men ikke desto mindre meget interessant læsning.

Jeg synes selv, at de historiske og arkæologiske artikler har været de mest spændende at læse - og det dækker jo faktisk en stor del af bogen. Afsnittene om bebyggelse samt broer og vadesteder er mine favoritter, men også artiklerne om vandmøller var spændende. Artiklen om lystfiskeriets historie fandt jeg meget fornøjelig, specielt om dets rødder som filosofisk gentlemansport.

\section{Det sure og det søde}

Et lille surt opstød gælder “indpakningen” på de næsten 2 kg vandløbs-kulturhistorie. Bogen fremstår i et kedeligt og konservativt omslags-layout, hvor detaljeringsgraden på de benyttede billeder er for høj til at kunne vises i et så lille format. De virker kort sagt lidt for gnidrede til et omslag. Sammenlign $\mathrm{fx}$ med de tilsvarende billeder på side 221 og 287. Omslaget er også lidt i disharmoni med sidedesignet, hvor man har tilstræbt et moderne udtryk. Således er der en farvelagt bjælke i faneblads-look foroven, hvori artik- 